\title{
İran Resim Sanatında Kaligrafik Eğilimler
}

\section{Özet}

Çağdaş İran resmi, kısa geçmişine karşın özgünlük arayışlarının yoğun olduğu bir süreç içindedir. Bu arayışta kimi zaman Batı resim kavramlarını öğrenme/öykünme biçimine dönüşmüş, kimi zaman tarihsel kaynakların yorumuna gidilmiştir. Bu bağlamda İslam kaligrafisinin İran resminde yorumu her iki açıdan değerlidir. Kaligrafi İran resminde başlıca iki biçimde uygulanır: Yazı niteliği korunarak ve soyutlama temelinde. Yazı motif olarak kullanııldı̆̆ında kaligrafı resmin konusuna bă̆ımlıdır. Araştırmacılara göre İran resim sanatında kaligrafik eğilimler 1950'lerde ortaya çıkmıştır. Bu eğilim bağımsız bir sanat tarzı olarak kabul edilmeden önce, bazı kıvılcımler ve emareler görülmeye başlanmış, ancak Saghakhaneh okulu ile birlikte çă̆daș soyut kaligrafi resim sanatı tüm benliğiyle yerini almıştır. İran sanatına yansıdığı süreçte pek çok sanatçı benzer eserler üretirken, zengin yerini almıştır. Iran sanatına yansıdı̆ı süreçte pek ç̧ok sanatçı benzer eserler üretirken, zengin
kaligrafi geleneğinin etkilerini de göz ardı etmemişleridr. Çağdaş İran sanat tarihçileri, Hossein Zenderoudi'yi bu eğilimin kurucusu olarak kabul ederler. Bu çalışmada söz edilen Sadegh Barirani, Mansoure Hosseini, Sadegh Tebrizi ve Mohammad Ehsaie, Nasrollah Afjeyi ve benzeri sanatçlar kimi doğrudan doğruya kaligraf, kimi ise hem kaligraf hem ressam sanatçı olarak kabul edilip eserleriyle değerlendirilmişlerdir.

Anahtar Kelimeler: Iran Resmi, Soyut Resmi, Saghakhane Okulu, Kaligrafik Eğilimler.

\section{CALLIGRAPHIC TRENDS IN PERSIAN PAINTING}

\section{Abstract}

Contemporary Iranian painting is in the process of intense search for originality despite its short history. In this quest, sometimes Western painting concepts have become a form of learning / emulation, sometimes interpreted historical sources. In this context, the interpretation of Islamic calligraphy in the Iranian picture is worthy of both aspects. Calligraphy is applied in two main forms in Iranian painting: On the basis of preserving the writing quality and abstraction. When the text is used as a motif, calligraphy depends on the subject of the picture. According to researchers, calligraphic tendencies in Iranian painting art have emerged in the 1950s. Before this tendency was accepted as an independent art stlye, some sparks and evocations began to be seen, but with the Saghakhaneh school, the contemporary calligraphic abstract painting art took place with all its self. While many artists in the process of Iranian art produced similar works, they did not ignore the self. While many artists in the process of Iranian art produced similar works, they did not ignore the as the founder of this tendency. Iranin calligraphic trends artists such as Sadegh Barirani, Mansoure Hosseini, Sadegh Tebrizi and Mohammad Ehsaie, Nasrollah Afjayi, etc., who were mentioned in this study some of them directly is a calligrapher and some of them is both calligrapher and painter artists concidered in the study with their works.

Keywords: Iranian Painting, Abstract Painting, Saghakhane School, Calligraphic Trends. 


\section{Giriş}

Resim ve yazı her zaman için yakın bir ilişki içinde olmuştur. Bilindiği üzere dünyanın çeşitli yerlerindeki mağara ve kayalıklarla bulunan resimlerin tarihi on beş bin yirmi yıl kadar geriye gidebilmektedir. Ancak yazının bilinen tarihi daha azdır. Ilk insanlar bilgileri aktarmak ve biriktirmek için doğal olarak resim-yazıyı seçmişlerdir. Zamanla yazının resim-yazı soyutlamaya dönüşüm sürecinde resimsel özellikler korunmuştur. Çağdaş sanatta gerçekçi resmin soyut resme dönüşmesinde olduğu gibi, orada da her karakter, belirli bir düşünceyi göstermek için tasarlanmıştır. Ancak fonetik yazı, mesajını hâlâ soyut resmin aksine semboller ve şifreler yoluyla taşır. Her durumda resim ve yazı arasındaki ilişki, ne soyut, ne de resim-yazı suretiyle interaktif bir ilişkidir. Kültürel bağlam ve sosyal hayattan uzak, kodlarını çözme olasıı̆̆ını ve iletişim rolünü ortadan kaldıran bir hat örneği, yani mesajına yabancı olduğumuz bir yazı sadece görsel ve resimsel olarak değerlendirilir (Caubet, 1998: 149). Bu sebeple-okuma yazma bilmeyen bir toplumda mesajların yazı yerine resimle verilmesi sebepsiz değildir. Konuyu İran ekseninde ele alacak olursak şunu görürüz: İran'da yazı, M. Ö. 2900 yılında, Proto-Elam yazısı ile başlamış ve bunu, saf soyutlamaya yönelen Fonetik yazıları, çivi yazısı ve daha sonra Pehlevi yazısı, ve Aramice ile Süryaniceden türeyen Avestayi yazısı takip etmiştir (Görsel 1).
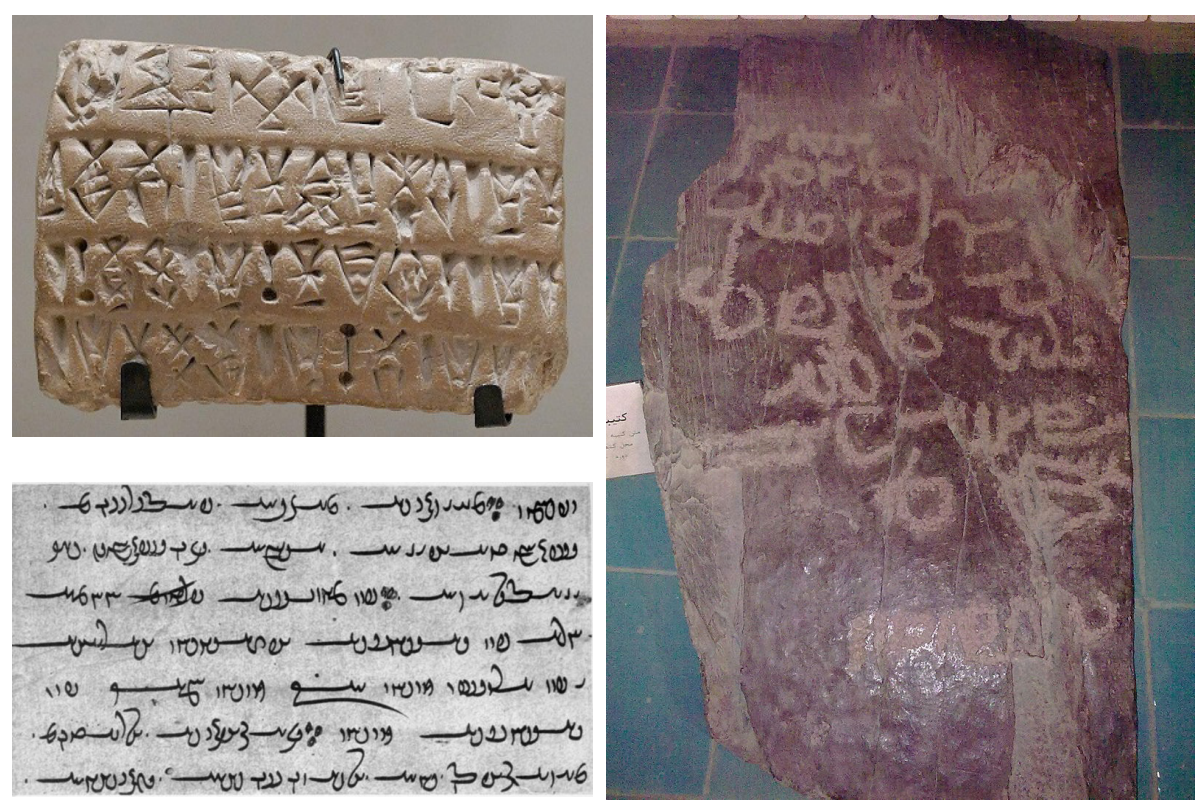

Görsel I. Proto-Elam, Pehlevi Yazısı ve Avestayi Yazısı.
Yazıların soyutlanmasıyla, harflerin anlamına daha derin bir estetik boyut eklemlendiğinden, bunlar, iletişim işlevini daha etkili şekilde yerine gelmiş olabilir. Resim ve illüstrasyon, daha nesnel olmaları yüzünden kitlelere mesajlarını doğrudan verebilir. Bu yüzden de toplumun tüm seviyelerine hitap etme olanağına sahip olduğu söylenebilir. Oysa yazı, gizemli, karmaşık ve büyülü bir unsur olarak özel zümrelerin gereksinimlerini sağlıyor denebilir.

I. Hürmüz ve Şapur'un kırallıkları döneminde kaligrafi ve minyatür, Maniheist sanatla birlikte yan yana oldular. Mani kaligrafisinde resmin doğal özellikleri (renk ve şekil) uygulanır. Bir sanat olarak Kaligrafinin resimle birlikte belki de ilk olarak kullandığı yer Maniheist resimler olup burada farklı kalınlıklarda yazı zengin renklerle yapılmış figürlerle birlikte yer alır (Bayani, 1984: 25) (Görsel 2).

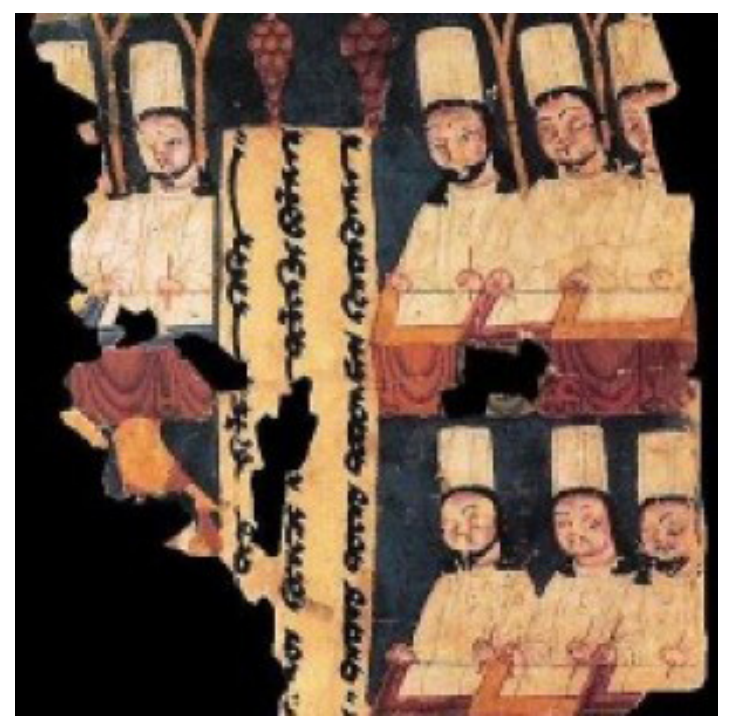

Görsel 2. Maniheist Kaligrafisi, Arjang Kitabından.

Diğer İslam coğrafyasında olduğu gibi İran' da da yüzyıllar boyunca kaligrafi özellikle kitap sanatlarında minyatürle birlikte yan yan kullanıldı. Bu durum modern resim sanatının başladığı Pehlevi dönemine kadar böyle devam etti. Ondan önce geleneksel minyatür tarzındaki resim, güzel hatla (hüsn-i hatla) yazılmış olan kitabın, ana değil, ikinci bir unsurduruydu. Nastalik hattın ortaya çıkmasından sonra, kaligraf, ressam tarafından Bu şekilde hat, minyatür ve şiir arasında form ve anlam açısından bir iletişim meydana geldi (Daneshvar, 1996: 437). 
13. Yüzyıldan itibaren kitap sanatlarının gelişmesiyle birlikte yazı-minyatür ilişkisi daha da canlılık kazandı. Bu birliktelik gayet estetik bir yazı olan nestalikin vücut bulması ve minyatürün zirveye erişmesiyle birlikte 15 ve 16. Yüzyıllarda en güzel eserlerini verdi. Bu tür eserlerde kaligraf, ressam tarafından belirlenmiş olan yerlerde münyatür üzerinde sanatını gösteriyordu, ressam da aynı zamanda kaligrafiden anladığı için kendi yarattığı resmileri süslüyordu. Bunlar arasında Behzad'ın elbette tartışılmaz bir yeri vardır. Nestalik; kufi, sülüs, rika ve talik gibi diğer hatlar arasında uyumlu bir şekilde levhalarda daha önce de kullanılıyordu. Fakat hem nestalik, hem de minyatür en başarılı örneklerini bu devirde, Behzad'ın elinden vermiştir. Nestalik ve diğer yazı tipleri ressam tarafından kalem ile resim üzerinde yapılıyordu. Kahire'de Mısır Milli Kütüphanesinde saklanan Sadi'nin meşhur Bostan isimli eserleri bunlardan biridir. Safevi dönemi Herat üslubuna ait bu bu resimde kaligrafi, kompozisyonda çok zekice temel eleman olarak kullanılmıştır (Görsel 3).

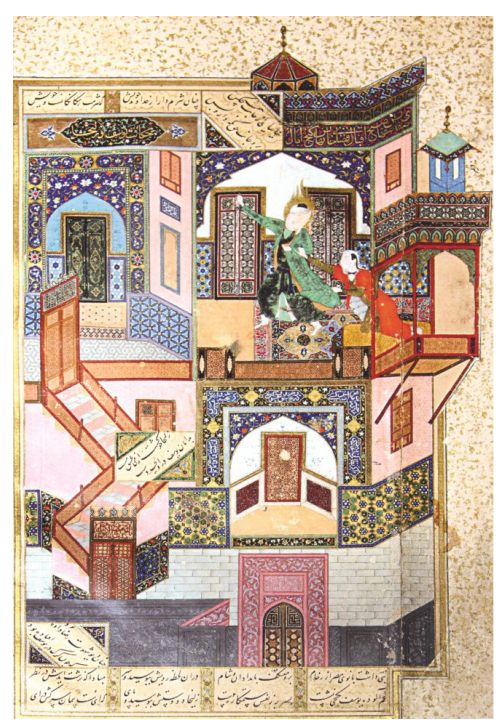

Görsel 3. Kemal ud-din Behzad, Youssef ve Zuleyha, Sadi'nin Bustanı,

Herat Okulu, MS./888 AH., 5/2I×5/30 cm, Kahire Milli Kütüphanesi. I 488,

\section{Sağahane Akımı: İran Resim Sanatında Kaligrafik Eğilimlerin Başlangıcı}

Pehlevi döneminin şahı Muhammed Rıza'nın, daha önce Paris'te mimari okuyan ve sanatsal devrimlere meraklı olan Farah Diba'yla evliliği, İran'ın farklı sanatlarının tanıtımına, gelişimine ve bazı kurumların yapılanmasına yardımcı oldu. Kraliçe Farah Diba, kültürel ve sanatsal işlerin hep kendi yönetimi altında olmasını isterdi. Sanatsal ve kültürel araçları kullanarak Pehlevi Hükümeti'nin modern ve aynı zamanda milliyetçi tarafını herkese göstermeye çalıştı. Bu faaliyetlerin, sansürün doruk noktasına ulaşmış olduğu zamanlarda olması bu faaliyetlerin tutarsız tarafıydı. Devletin tutarsız kültürel politikasına rağmen, kraliçenin özel büro faaliyetleri 1960 'larda sanat eğilimlerini yönlendirmede önemli rol oynadı. Bu büro kontrolünde kültür ve sanat dalında, birçok kurum ve organizasyon açıldı ve faaliyet gösterdi. Farah ve iş arkadaşlarının yönetimindeki bu büronun hedefi umumi bir eğitimle toplumun zevk seviyesini yükseltmek ve onları modernizmi kabullenmeye hazırlamaktı (Diba, 1971: 12-13, 48-49).

Farah'in hırsının doruk noktası, başkanlığını yaptığı Shiraz Kültür ve Sanat Şenliğiydi, Kraliçe bu sayede İran'ı eski kültüre ve sanata sahip olmasına rağmen, geleneksel ve modern sanatın karışımını sunmaya hazır bir kapasiteye sahip olduğunu göstermek istiyordu (Diba, 1970: 12).

Bu geleneksellik ve modernizmin karışık konuları, değişik yeni eğilimlerin ve hareketlerin gelişmesine, İran kaligrafi mirasına yönelmeye sebep oldu. Yeni Kaligrafik eğilimdeki sanatçılar, entelektüel, toplumsal ve siyasi atmosfer etkisi altında, eski görsel mirası ile çağdaş sanat dili arasında ilişki kurmaya çalışmaya başladılar (Natel Khankari, 1989: 72-76). Onlar, sanatçının kişiliğini şekillendiren faktörün, düşünceleri modern şekilde aktarmak olduğunu anladılar. Bu yüzden genelde geçmişten gelen kaligrafik bir form veya unsuru eserlerine yerleștirdiler. 60'lı yıllarda İran soyut sanat içinde kimlik arayışları ile ilgili tartışmalar ve gelişmeler, Sağahane okulu ile birlikte başlamıştır. Bu okulun sanatçıları 1960 sonrası İran resmindeki soyut etkiler ve kaligrafik eğilimlere yönelik atılan adımlarla birlikte süreklilik kazanmıştır. Bu eğiliim, milliyetçi avam sanatının desenlerini ve elemanlarını kullanarak, kaligrafiyi ve geleneği vurguluyordu. Kaligrafik elemanları modern bir şekilde kullanan bu eğilimin şekillenmesinde şu dört temel husus belirleyici olmuştur:

1) Batılaşmanın karşıtı olan milliyetçilik ve eskiye dönüş,

İran toplumunun istediği değişiklikler, entellektüeller arasındaki oluşan bakış açısı devrimleri,

2) Hükümetin dolaylı yoldan kültürel modernleşme programları ve buna bağlı olarak sanat merkezlerinin açılması; burs, bianel ve sergi faaliyetlerinin artması,

3) Siyasi istikrar ve toplumun ekonomik olarak gelişmesi (Milani, 2009: 141), 
4) İran entelektüellerinin, Avrupa'da başgösteren modernizm, popüler kültür, yerel kültür ve post modern sanat üzerine yapılan tartışmalardan ve öğrenci hareketleri, hipicilik ve sosyalizm gibi toplumsal ve siyasi olaylardan etkilenmesi.

Sağahane sanatçıları Batı modern sanatını ve eğilimlerini araştırarak, İran kaligrafi miraslarını uygulayıp modernizmle birleştirerek dünyaca itibar kazanmaya çalışıyorlardı (Tanavoli, 2009: 69). Bu yüzden, bu sanatçılar, birçok el sanatı ile Iranlı geleneksel kaligrafi sanatlarını keşfetmeye başladılar. O zamana kadar halk arasında kullanılan usturlaplar, basmalar, mühürler, kolyeler, tılsımlı gömlekler, taziyede kullanılan sancaklar, yöresel el sanatları motifleri (kilim ve halıda), eski dönem çanak çömlekler, kırk anahtarlık gibi dini eşyalar, Kaçar sanatına ait elemanlar, üzerinde atlı binici resimleri olan sırlı kâseler, kaligrafi ve İan minyatüründen başka Ahamenid ve Sasani dönemine ait levhalar, yazıtlar, Asur kabartmaları, İranlı ressamların hemen ilgisini çeken konular oldu. Yine İran şiiri, doğu irfanı ve semboller de çağdaş İran resim sanatında yerini almaya başladı (Diba, 1989: 152).

Sağahane okulu sanatçıları görsel yazı teknikleri dışında, hayvan ve özellikle kuş formları ile kompozisyonları ortaya koyduktan sonra, resimlerine kaligrafinin bazı elemanlarını da dahiletmeye başladılar. Böylece birtür görsel eserler "Çizgi-Çizimi" (Resim-Hat) (Resim-Yazı) (Kaligram) diyebileceğimiz bir eğilim ortaya çıktı. Dolayısıyla harflerden ve kelimelerden oluşan bir tür soyut resim sanatı şekillendi. Bu seçim ve tercihe, bazı sanat-kültür grupları ile basın da güzel bir destek verdi. Bu eğilim çok yönlü ve sentetik soyut bir sanat eğilimiydi. Resimlerde sık kullanılan geleneksel kaligrafik teknikleri bir yazı türünü tanımlamak için kullanılmaktadır. Aslında bu eğilimin öncüleri Kaçar döneminde görülebilir. Ama bugünkü yaygın şekli Sağahane hareketinin doğumundan sonra meydana çıkmıştır.

Çalışmalarında kaligrafiyi soyut bir kompozisyonla birincil referans olarak kullanan Sağahane okulunun kurucusu H. Zenderoudi'nin ardından, Mohammad Ehsaie, Reza Mafi ve Nasrollah Afjeyi, gibi sanatçllar da bu resim-çizgi üslubunu kullanmaya başladılar. Resim-çizgi eğiliminde çalışan sanatçılar, ilham kaynağı olarak geleneksel kaligrafiden istifade etmişlerdir. Ama bunu yaparken, sanatçı hat sanatının kutsal yönünü ihmal etmemişlerdir. Sağahane sanatçılar daha çok laik anlayışa meyili iken resimçizgi sanatçıları kutsal ve edebî kavramlar ile büyülendiler diyebiliriz.

Sağahane sanatçıları, kaligrafi elemanlarını soyut formları organize etmek için kendi yeteneklerini ve birikimlerini kullandılar. Bu grubun en önemli amacı çağdaş sanat tarzlarına uygun ve aynı zamanda yöresel formları yansıtan eserler yaratmaktı. Bu yüzden geleneği kullanmada ve kültürel sorunların çözümünde onların yanıtı hep laik yönde oluyordu. Onlar için kaligrafinin temel şekilleri ve tanınmış yazı tipleri, yalın veya kombinasyon halinde, çok önem taşıyordu, ama her hangi sabit bir kural görünmüyordu.

İran resimde kaligrafi şekillerinden esinlenmiş formları kullanmak ilk defa Sağahane sanatçıları tarafından 1964 yılında Hossein Zenderoudi'nin eserlerinde göründü. Ve bir müddet sonra bu eğilim üç temel eğilim halinde ayrışarak karşımıza çıktı.

1. Hossein Zenderoudi, Faramarz Pilaram, Tabrizi, Hosseini, Barirani gibi soyut kaligrafik ressamlar.

2. Ehsai, Mafi, Afjeie gibi soyut geleneksel kaligrafik ressamlar.

3. Ajali, Rasouli gibi geleneksel kaligrafik ressamlar.

\section{Soyut Kaligrafik Eğilimin Ressamları}

Sağahane okulun kurucusu ve şimdiye kadar İran resim sanatının en ünlü ismi olarak kabul edilen Hossein Zenderoudi'nin özgün bir kimliği vardır. Hossein Zenderoudi kaligrafiyi, soyut kombinasyonlarının temel elemanı olarak kullanan ilk İranlı sanatçı olarak bilinir. O, yalnızca resimleri ile değil, yaşam tarzı ile de çağdaşlarından ayrılır. İran-İslam'ın eski kaligrafisine ve zengin geleneklerine dikkat ederek, soyut kaligrafik eğilimlere adım attı ve doğal olduğu kadar da açık görüşlü bir şekilde sanatsal bir tarz yarattı. Zenderoudi'nin tuvallerinde diğer Sağahane sanatçılarının aksine, kaligrafi; edebi ve dini içeriğini kaybederek, Dadaist eğilime benzer, soyut-ritmik atmosferler yaratıp süs elemanı olarak kullanılmıştır (Zenderoudi, 2001: 23).

Zenderoudi'nin soyut kaligrafik eğilimliçalışmalar, kendini ifade edebileceği, iletişim sağlayıcı, geleceğe taşıyabileceği bir araç olmakla birlikte, ayn zamanda onun çocukluğunu ve gençlik yıllarını geçirdiği İran'da elde ettiğ bilgi kaynağıdır da. Bu süre zarfında sanatçının kaligrafik çalışmaları bir di olarak sanatçının sanat hayatındaki yerini almıştır. Zenderoudi'nin eserinde (Görsel 4) bakıldığında, İran İslam alfabesindeki harflerin bir patlama sonrası kaza eseri oluşan lekelere benzediği görülür. Eserindeki nesneler, derin duygularla ve kendiliğinden doğaçlama olarak ortaya çıkmış gibi bir izlenim verir. Buradaki çizgi, fırça darbesi ve damlatma tekniği, sanatçının kendine özgü yeteneğini ve bunları tuvale aktarma şekli, sanatçının aktif bir şekilde varoluşunu gösterir. Esasen resimdeki her nokta bilinçli bir seçimin 
ürünüdür. Eserdeki bütün bu özellikler sıra dışı deneyimi ve çalışmayı gerektirmektedir. Zenderudi'nin eserlerinin çoğu, kaligrafik unsurların rastlantısal düzenle bir araya getirildiği, hareketli bir soyut ve serbest bir çalışma olarak kabul edilir. Nitekim sanatçı, bu çalışmayı yaparken, elinin, kendisinin bilmediği içsel bir güç tarafından yönlendirildiğini belirterek, istençdışı yapıldığını açıklamaktadır.

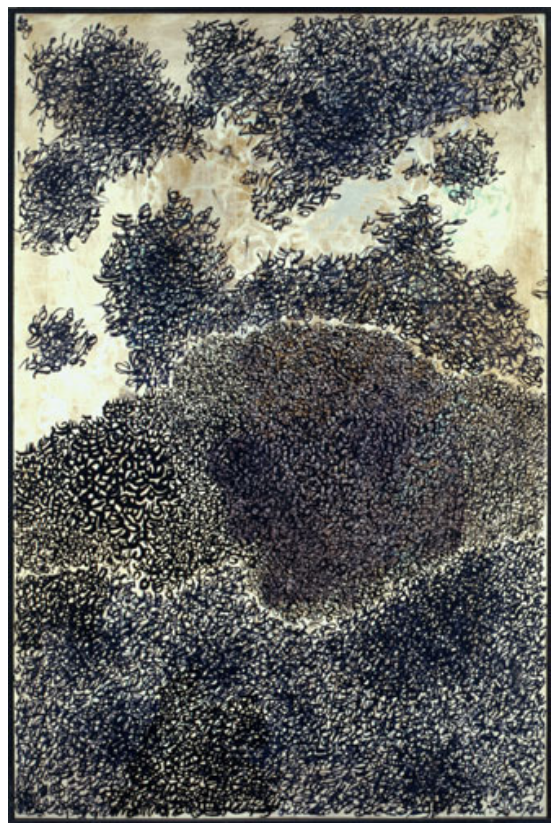

Görsel 4. Hossein Zenderoudi, Sanatçının Dört Yolu, 1964, Keten Üzerine Yağlıboya, $150.5 \times 100 \mathrm{~cm}$, Grey Art Gallery, New York University Art Collection, Gift of Abby Weed Grey, 1975. 123.

Bandar Anzali'de 1923'de doğumlu Sadegh Barirani, Tahran Üniversitesi Güzel Sanatlar Fakültesinden diplomasını alıp fotoğraf, resim ve grafik gibi görsel sanatların farklı alanlarında deneyimlere sahip olmuştur. Yurtdışında okuması ile çağdaş sanatın kendisinin iyi bir bilgiye sahip olmasına sağlamıstır. Fırça ve metal kalemleri etkili bir araç olarak tuval, karton vb gibi farklı düzeylerde kullanılmaktadır. Uzak Doğu kaligrafik geleneği ve soyut ekspresyonizmden etkilenen Barirani eserlerinde sınırlı renklere yer vermektedir (Tabrizi, 1985: 17). O, soyut kaligrafik eserleri oluşturmak için siyah, beyaz ve grinin tonlarını; tarz olarak da geleneksel Çin kaligrafi ve İslam-Iran hat sanantın ortak özelliğini kullanıyor (Görsel 5).
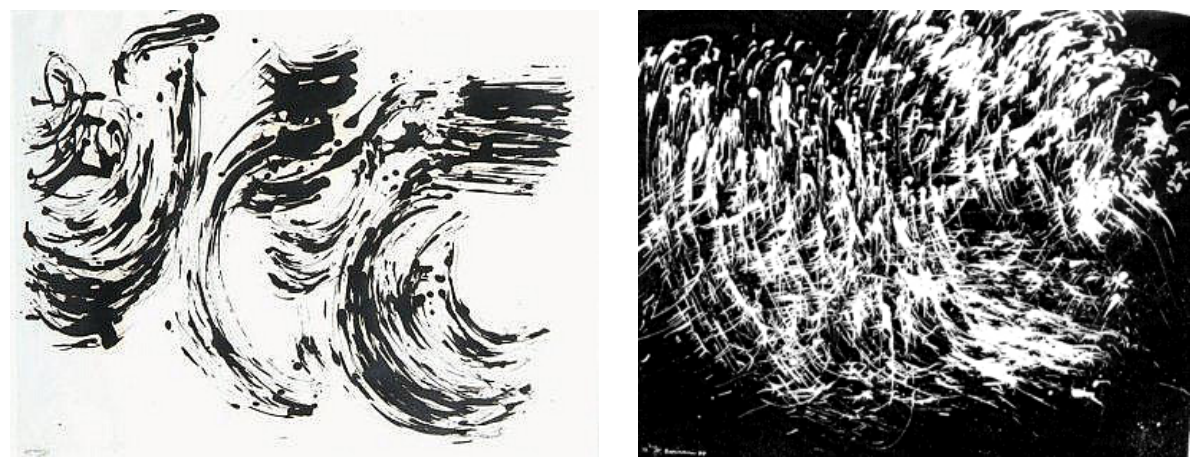

Sadegh Barirani, i̧̧̇inde Doğmuş, 1923, Kağıt Üzerine Yağlıboya, 50x80cm.

Kozmik 2, 1978, Kă̆ıt Üzerine Yağlıboya, 50x40cm.

Mistisizme bağlı olduğu görülen ressam Barirani, "Zarin Kelk" adlı bir derviş ile sanat dünyasına ilk adımını atmıştır. Üniversiteden mezun olduktan sonra geleneksel İran kaligrafi sanatında eser verenlerle, özellikle de Safevi döneminin en önemli hattatlarından biri olan Reza Abbasi'nin çalışmaları ile ilgelenmiştir. Buna rağmen, onun tarzı Doğu kökenlidir, çünkü onun ruhu meditasyon ve gözleme dayanan Ortadoğu felsefesinden besleniyor. Barirani'nin eserleri iki gruba ayrılabilir: İran'da yaygın olan nestalik kaligrafisine yakın eserler ve Kozmik uzantı olarak kabul edilen diğer çalışmalar (Görsel 6).

Barirani'nin oluşturduğu soyut resimler, tasavvuftan etkilenmiş olduğu halde aynı zamanda Sürrealizmdeki otomatizmin ve Uzakdoğu sanatındaki meditasyonun izlerini de taşımaktadır. Çok ilginç şekilde, Barirani çalışmaya başlamadan önce stüdyosunda özel bir ritüel yapıyordu (Ibid: 24). Illk olarak Sufi melodileri ve ilahi kayıtlarını dinliyor, sonra mistik şairlerin şiirlerini yüksek sesle okumaya başlıyor, böylece coşuyor ve duygularını tamamen hareketli bir biçimde kağıt üzerinde aktarıyordu. Duyguları doruk noktasına ulaştığı birkaç dakika içinde kendisinin bile okuyamadığı yazıları, içgüdüsel olarak yazmaya başlıyordu. Barirani'nin bu yolculuğundan tamamen soyut kaligrafik bir eser meydana gelmektedir. Barirani'nin bu yolculuğu sonunda resim, formun verebileceği ifadenin ötesine geçer. Ressam, konvansiyonel renk spektrumunu bir kenara bırakıp herhangi bir renkten daha fazla ışığı yansıtan beyaz renk ve renksizliğin en tepesinde olan siyah rengi kullanarak çok çarpıcı etkiler yaratıyor.

Mansure Hosseini (1936 d.) İran'ın çağdaş ressamlarından biridir. Liseden sonra Tahran Üniversitesi Güzel Sanatlar Fakültesi'nde okudu. Tahran Güzel Sanatlar Fakültesi ve Roma Güzel Sanatlar Akademisinden mezun 
olan Mansoure Hoseyni resimlerinde kaligrafi şekillerini kullanmaya çalıştı. 1962 yılında Sağahane okulu ile tanıştı. O zamandan beri eserlerinde İran ve Arap kaligrafisini renkli ve ekspresyonist bir anlayışla kullandı (Görsel 7) Soyut eserlerindeki kalın renk kullanımını ve kalem vuruşlarını başka hiçbir kaligrafi tarzında göremiyoruz. Ama hareketli yazı gibi görünen eserleini, onun kaligrafi eğilimi ile ilişkelendirebiliriz (Pakbaz; Emdadian, 2002: 13).

Hosseini 60'ı yılların başında Farsça kaligrafiden yararlanarak, soyut eserler yaratmışıı. Sanatçının resimlerinde farklı dönemlerde eserleri arasında birlik görülebilir. Onun eserlerinde gölgeler, renk yoğunluğu, kalın çizgiler, kûfi yazılar her eserde ortak olarak kullanılmıştır denebilir.

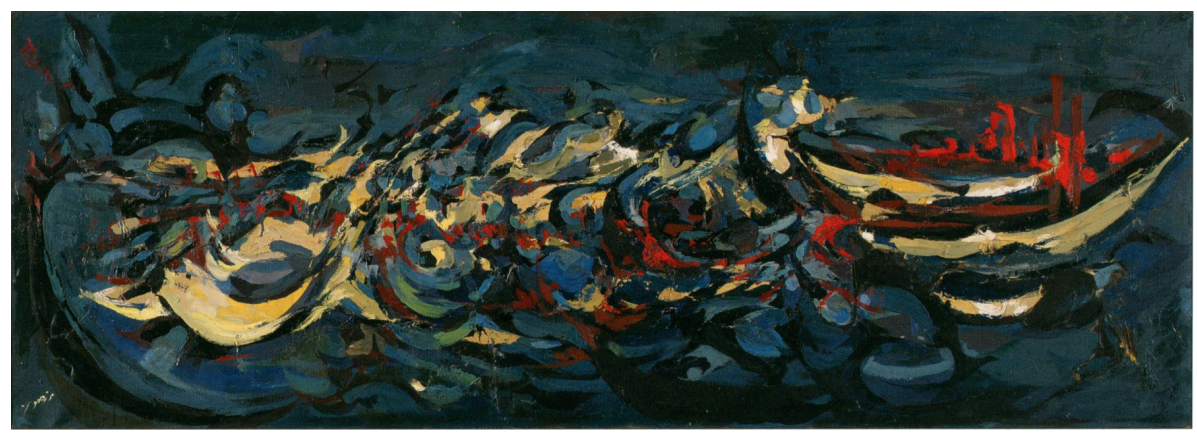

Görsel 7. Mansoure Hosseini, Anonim, 197I, Tuval Üzerine Yağlıboya, $200 \times 70 \mathrm{~cm}$.

Tamamen hat kurallarından uzak olan Hosseini bir hattat değildi, ama elbette ait olduğu kültür sebebiyle, harflerin ardındaki çeşitli sırları, sembolleri ve İslam hat sanatının soyut formlarını ve özellikle kûfi hattın özelliklerini biliyordu. Kufi'nin basit ve saf formların gücü Hosseini'nin karmaşı renklerle dolu eserlerin ortamında zayıflatılarak yer alır. Kufi yazılar düzenli ve geometrik bir ortamda olsaydı eser daha derin tesir uyandırabilirdi. Belki de nestalik hattın keşideleri ve kıvrımları onun eserlerinde daha fazla uyumlu olabiridi. Onun eserlerinde kufinin kullanımı, bir bestekarın bestesinde hammaddee olarak türküleri kullanması gibidir. Hosseini, Kufilerin şarkııını renk ve formlarla yapıp son olarak, şarkıya âdeta soyut tını verme yoluna gitmektedir (Görsel 8).

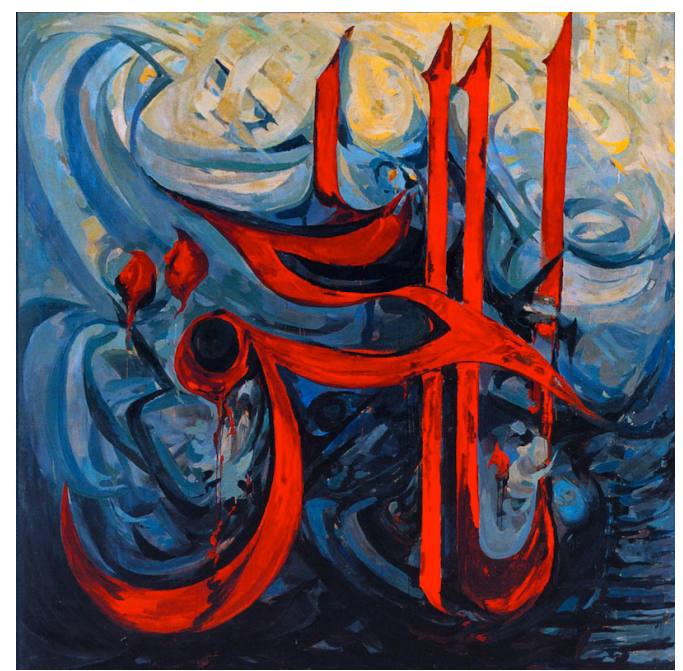

Görsel 8. Mansoure Hosseini, Anonim, 1972, Tuval Üzerine Yağlıboya, $120 \times 70 \mathrm{~cm}$.

Sadegh Tabrizi (1938 d., Tahran) İran'ın soyut kaligrafik eğilimlerin kurucuları arasında yer alıp yine Zenderoudi, Pilaram gibi, Tahran Tezyini Sanat Okulunun ilk öğrencilerinden biriydi. İlk olarak, sadece resim değil, kaligrafi ile süslenen çanak çömlek gibi çalışmalarıyla ün kazandı. Sadegh Tabrizi, hayvanların derisindeki kırışıkıkları ve doğal renk tonlarını bazen geniş, bazen dar, geometrik ve dalgalı kaligrafininin içinde ritmik olarak kullanarak, form ve renk ahengi yaratmada özgün ve yetkin bir ifadeye erişti. Sanatçı, tabaklanmış deri üzerinde ince çizgilerin siyah Çin mürekkebiyle uyumlu şekilde kullanımı ile özgün eserler vermiștir (Emami, 1977: 17). Bu eserler Fransız sanat bilim adamı ve oryantalist Michelle Tapiyeh tarafından seçilip 1971 yılında Paris'te "Cirrus" ve Tahran'da "Burgues" Galeri'de sergilenmiştir. Bu dönemde onun, belirsiz ve dağınık harfleri resmin bir kenarına istif ettiği görülüyor. Tabrizi, bu eserelerin meydana gelme nedenlerini "yalnız bir çerçeve içine betimlenmiş olan ve boşlukta dağınık halde duran okunaksız bu yazıların her biri bir etkiye sahip olup uyumlu ve güzel bir kompozisyon oluşturulabilmiştir" diye açıklıyor (Görsel 9) (Shamkhani, 2003: 166).

Tabrizi'nin eserlerinde renk geçişleri sınırlıdır. Nestalik ve Şikeste nastalikle yazılmış yazılardaki kalem hareketleri soyut bir resimde soyut bir kaligrafiyi elde etmek için bilinçli şekilde yapılmışır. 


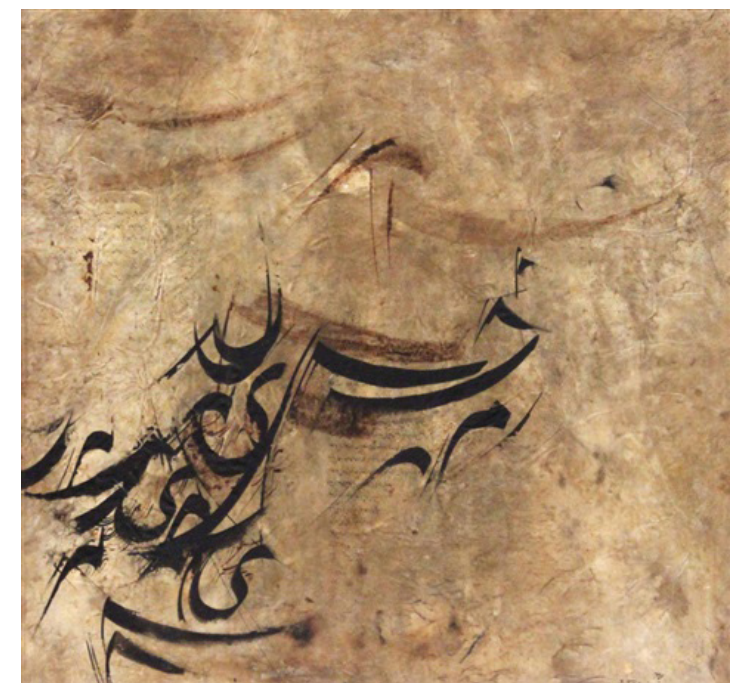

Görsel 9. Sadegh Tabrizi, Anonim,1959, Tabaklanmış Bir Deri Üzerine Yağıboya.

Tahran Güzel Sanatlar Fakültesi mezunu Faramarz Pilaram, bir süre Zenderoudi'nin izinden gittiği görülüyor. Onun sanatındaki kelimeler, harfler ve geometrik şekiller, Şii resim etkisi gösterir. İlk çalışmalarında, eski mühürlere benzer bir doku yaratmak için geometrik kombinasyonlardan istifade etti. Fakültedeki eğitimi döneminde Batı modern sanatından etkilendiği görülebilir; o Pit Monderian ve Alexander Kalder mimarisine ve geometrik yapısına hayran kaldı. Yetenekli bir kaligraf olan Pilaram, daha sonra, kaligrafide, özellikle de nestalikte tecrübelerine devam etti (Pakbaz, 1999: 46). 1970'li yılların sonu ve 1980'li yılların başında kaligrafi formundaki renkli tuvallerden esinlenerek, Ekspersiyonist resimler yarattı, bu eserleri eski yazıtlarla bağdaştırabilirz. Daha sonraki dönemlerde kaligrafi elemanları, geometri kombinasyonlarda doku olarak kullanıldı ve bu eserlerde şeffaf renklere, özellikle de altın ve gümüşi renklere yer verdi. Bu teknik Pilaram eserlerine üç boyutlu ve kabarık bir hava kattı. 1975 yilında Iran ve Amerika Derneğinde düzenlenen sergide, tek harflerden, tek renklerden, ritim ve görsel hareketlilikten yararlandı; kendisi bunu birlik olarak tabir etti. İddaasına göre, Litrizmi yaratmak kaligrafi değerlerinden uzaklaşmaktı (Ibid: 56). Pilaram'ın Tahran Çağdaş Sanatlar Müzesi'ndeki bazı resimlerinde, kelimelerin görsel senfonik bir atmosferi var (Görsel 10). Aslında sanatların homojen özelliği- müzik, șiir ve resim- onun eserlerinde zekice simetrik bir şekilde karşımıza çıkıyor. Pilaram'ın çizimlerinde yan yana duran kaligrafi elemenları, onun figüratif formları harfler ile birleştirmedeki yeteneğini gösteriyor (Görsel 11).
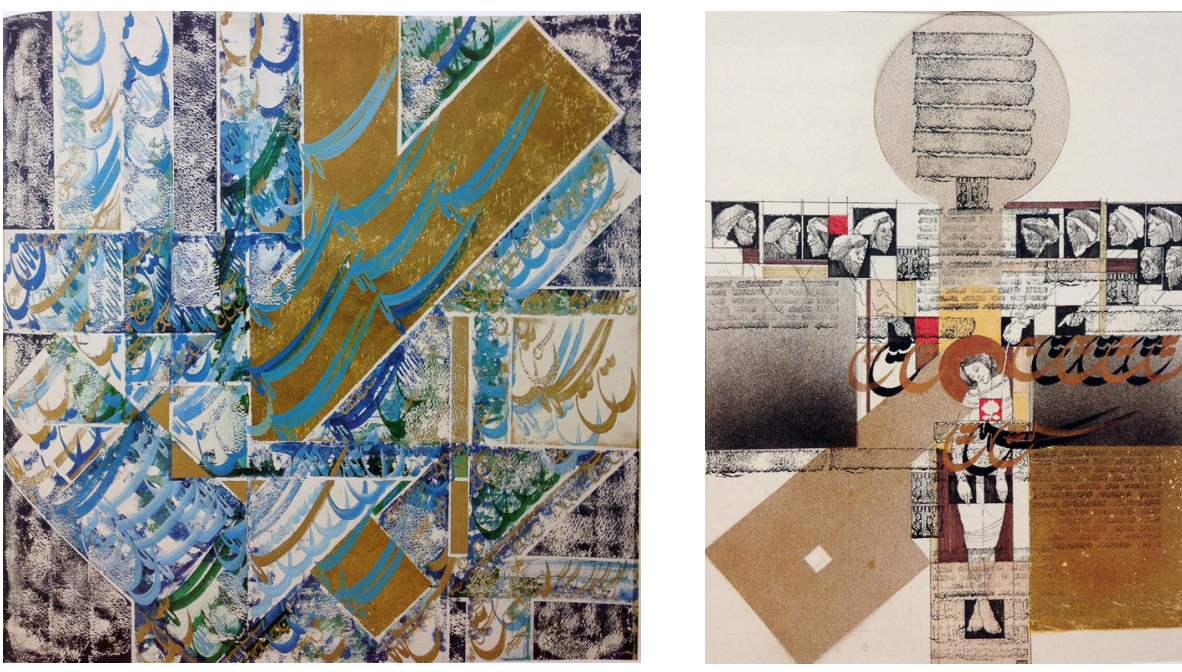

Görsel 10-II. Faramarz Pilaram, Anonim, 1970, Tuval üzerine yağlıboya, $105 \times 105 \mathrm{~cm}$ Yusuf ve Zeliha 13., 1977, Kartun üzerine karışık malzeme, 60x44 cm.

Kamran Katoozian, Gholam Hossein Nami, Kamran Diba gibisanatçılar, 1971 yılından sonra Sağahane Okuluna mensup sanatçıların çalışmalarından ilham alıp kaligrafi motiflerini kullanarak çok sayıda eser yarattılar. Bu sanatçılar ritim ve hareketi tuvallerde iki boyutlu kullanarak, diğer soyutçu sanatçılar gibi, harflerin ve yazıların formuna edebi anlamından daha çok önem gösterdiler. Tuvallerdeki kendiliğinden olan hareketler kaligrafinin tanınmış elemanlarıdır (Görsel 12-15).

Bu grubun başka bir sanatçısı olan Bahzad Golpayegani eserlerinde Farsça "ha" harflerinden oluşturduğu estetik kompozisyonları dokusal bir yüzey görünümüyle leke gücüne dayanarak başarmıştır. Kısaca, o, Parviz Tanavoli'nin kaligrafik çalışmalarından hareketle, Farsça alfabenin bir harfini seçip en aza indirgediği bir espas oluşturmuştur.

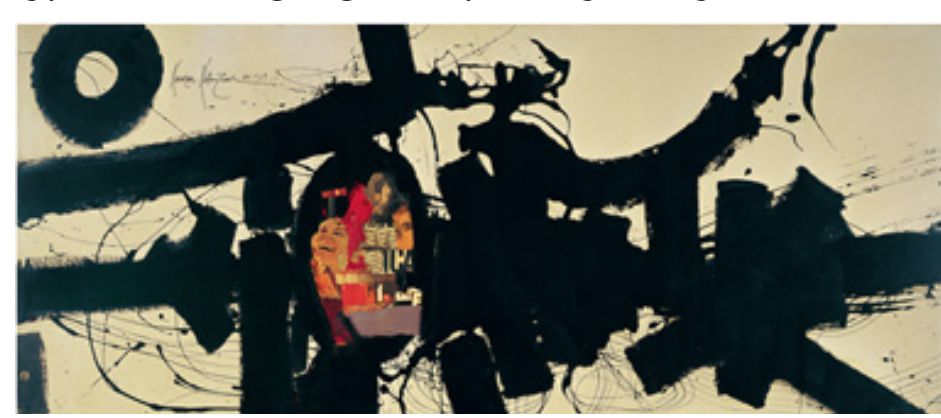

Görsel 12. Kamran Katoozian, Siyah ve Beyaz, 1964, Tuval üzerine karışık malzeme, $283 \times 121 \mathrm{~cm}$ 

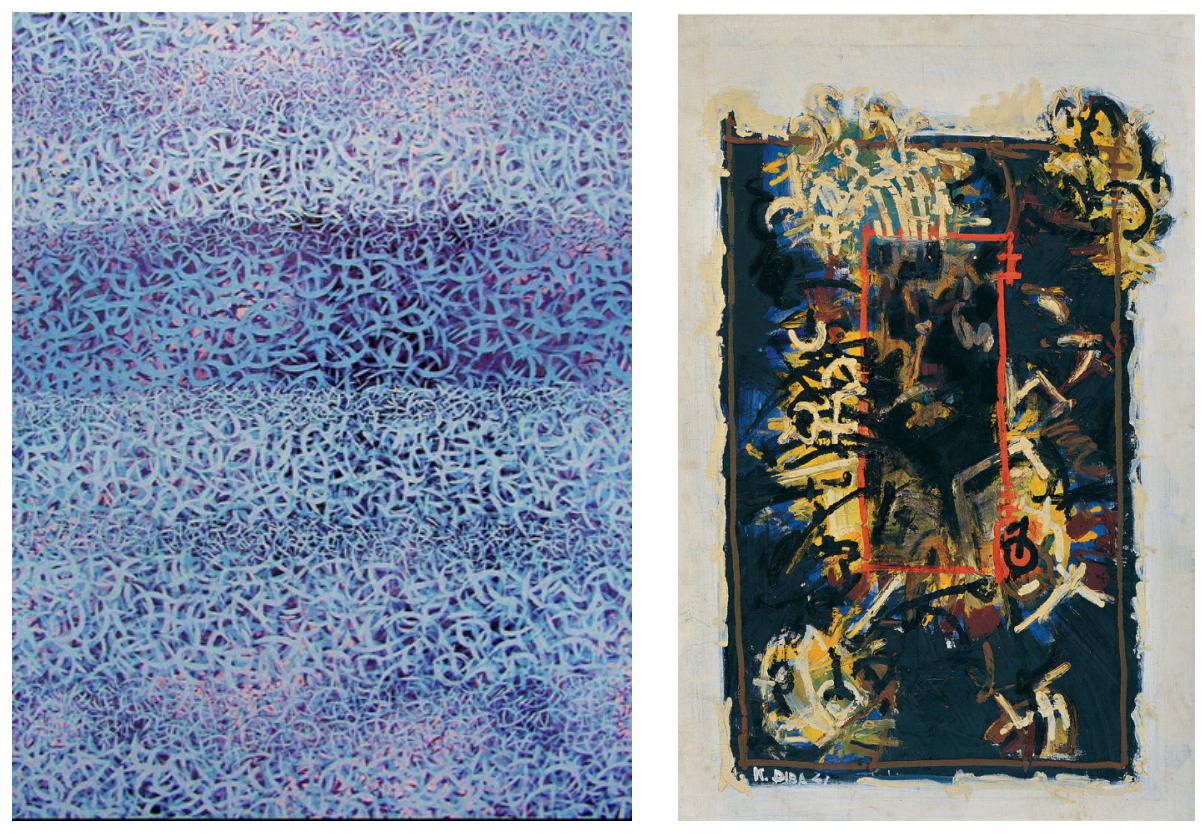

Görsel 13. Gholam Hossein Nami, Anonim, 1977, Tuval üzerine yağlıboya.

Görsel 14. Kamran Diba, Anonim, 1977, Tuval üzerine yağlıboya, 122x79cm.

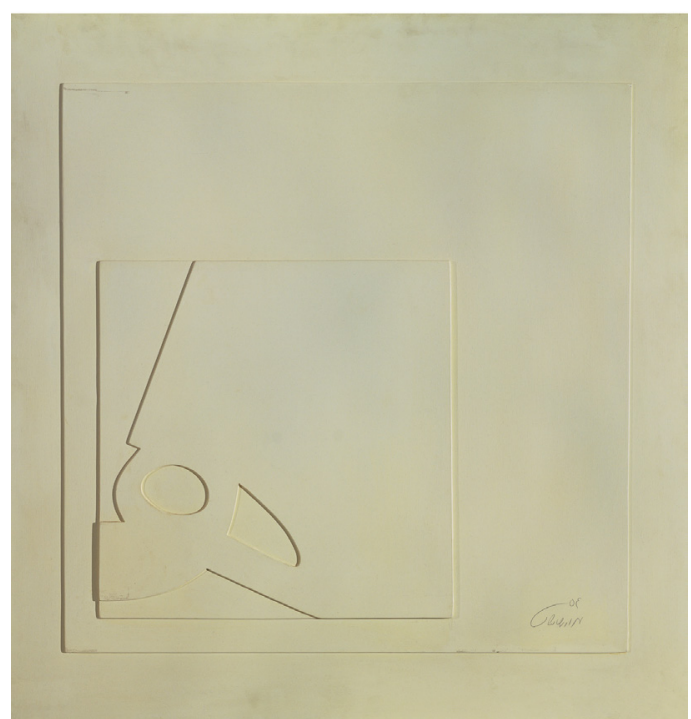

Görsel 15. Bahzad Golpayegani, Hiç-Hapis, Tuval üzerine karısıı malzeme, $1977,100 \times 100 \mathrm{~cm}$.
Bu grupta yer alan seramik sanatçısı, heykeltıraş ve ressam Fereydoun Mam Beygi (1940-2009) profesyonel sanat hayatına İran İslami Cumhuriyet devriminden sonra başladı. Tahran Güzel Sanatlar Fakültesi ve Roma Güzel Sanatlar Akademisinde mezun olan bu sanatçının eserlerinde letirizm elemanlarını Uzak Doğu özellikleriyle görebiliriz. Modern soyutlamaya inanan Mam Beygi'nin tuvalleri, özellikle de 1990 ve 2000'li yıllarda yaptığı resimler, kaligrafi elemanlarını farklı şekillerde kullanan savaş sonrası Amerikalı soyut ekspersiyonistlara yakın ilgi duyduğu açıkça belli oluyor. Resim tuvalleriyle materyallerin birleşimi, İslam kaligrafisini ve uzak doğu sanatının modernizme dönüşümünü gösteriyor (Görsel 16).

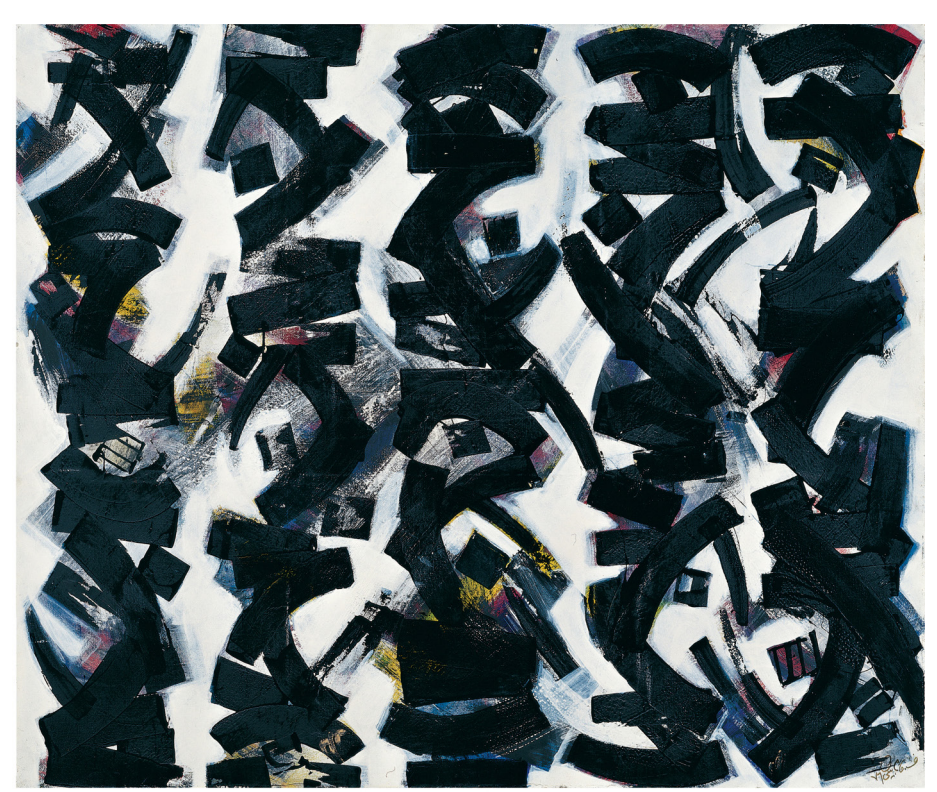

Görsel 16. Fereydoun Mom Beygi, Beyaz Uzay Gemisi, Tuval üzerine karışık malzeme, 1977, $110 x 110 \mathrm{~cm}$.

Soyut sanattaki kaligrafik eğilimlere sahip olan sanatçılar, mesleklerine devrimden sonra da devam ettiler. Devrimin ilk yıllarında, İran minyatürü, klasik şiir gelişme gösterdi. Devrimden sonra 80'li yıllarda Zia-e-din Emami gibi bazı ressamların eserlerinde görüldüğü üzere, kaligrafi soyutlanarak çizgiler halinde ana görsel eleman olarak kullanılmıştır (Görsel 17). 


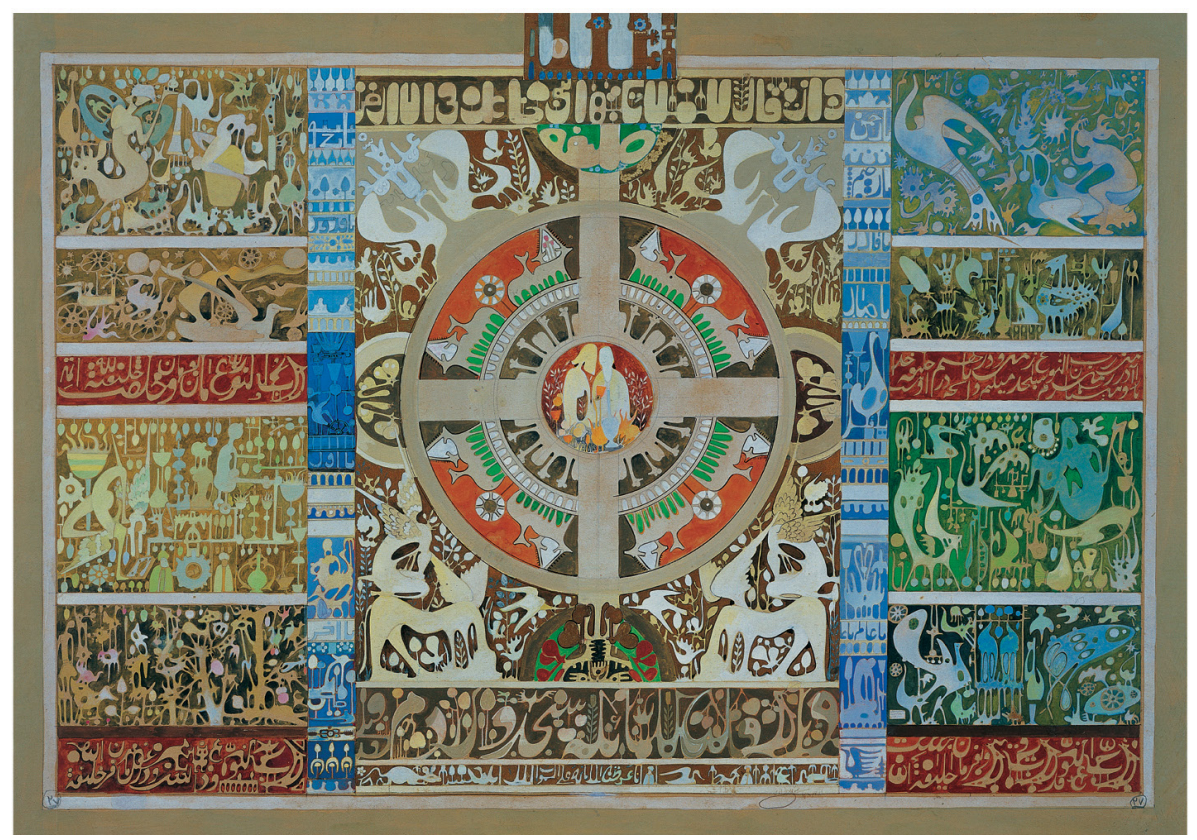

Görsel 17. Zia-e-din Emami, Adem'in Yaratılışı, 1987,

Tuval üzerine karışık malzeme, $74 \times 50 \mathrm{~cm}$.

Koorosh Shishegaran, Iraj Karimkhan ve Mohsen Vaziri Moghaddam gibi grafistler 1980 ve 1990'lı yıllarda faaliyet göstermiş olup bunların düşünceleri daha çok Sağahane mektebine yakındı. Kaligrafi tuvallerindeki renkli formlar, edebiyatiçeriğini aktarmakiçin kullanılmıyordu. Aksine renkli iki boyutlu kaligrafiler, Farsçayla gizemli bir hava yaratmak için kullanıımıştı (Görsel 18-20).

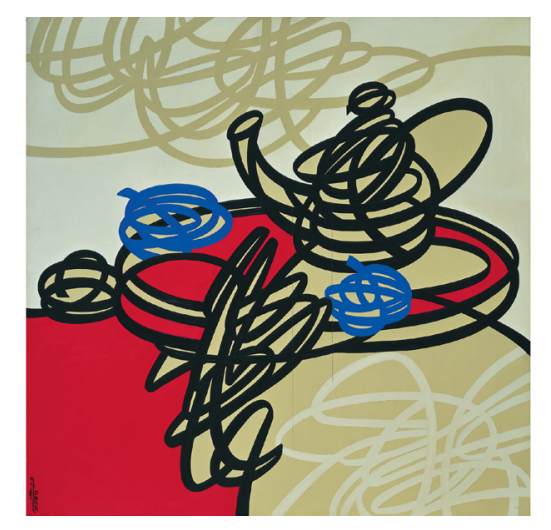

Görsel 18. Kourosh Shishegaran, Anonim Tuval üzerine yă̆lıboya, $1988,90 \times 90 \mathrm{~cm}$.

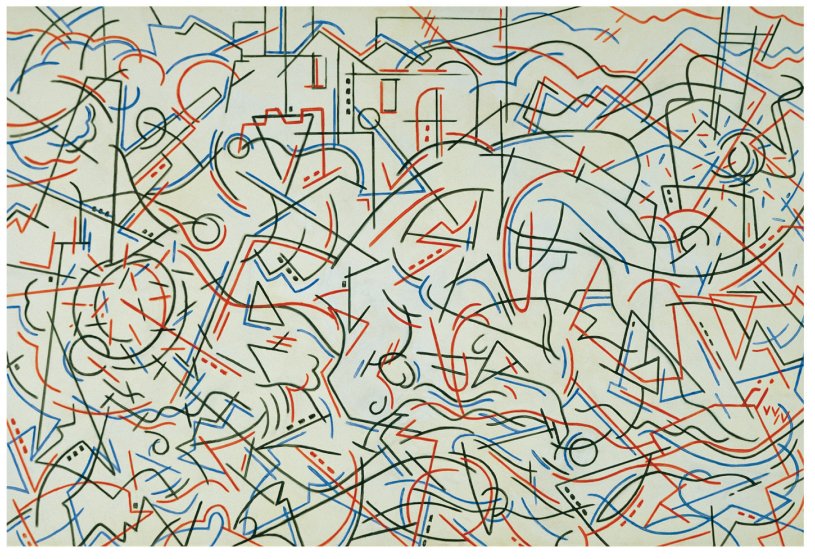

Görsel 17. Zia-e-din Emami, Adem'in Yaratılışı, 1987, Tuval üzerine karışık malzeme, $74 \times 50 \mathrm{~cm}$.

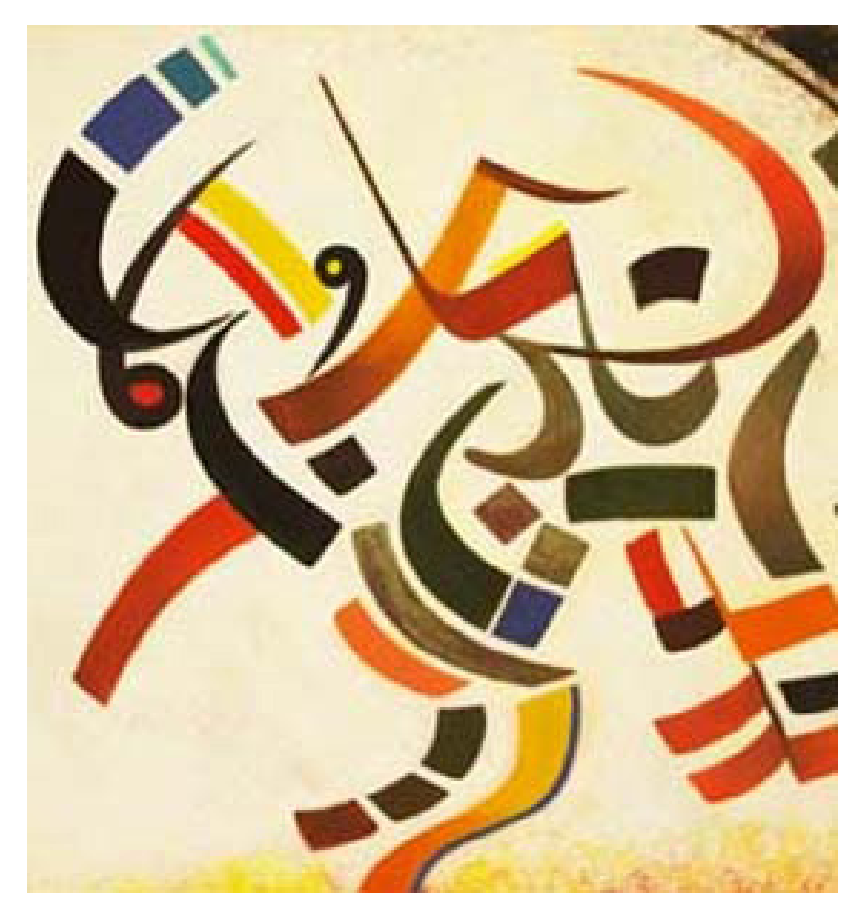

Görsel 20. Mohsen Vaziri Moghaddam, Kompozisyon, 1997. Kartunüzerine akrilik, 29×30cm.

Bu grubun başka bir sanatçısı olan Sedaghat Jabbari (1961) 1990 yılında soyut sanattaki kaligrafik eğilimlere yöneldi. Jabbari kelimeleri ve şekilleri birleştirerek ve hat sanatının kaidelerine dönüş yaparak soyut eserler 
verdi. Hem geleneksel kaligrafi eğitimi, hem de grafik tasarım bölümünde eğitim gören Jabbari, ikisini birden eserlerinde birleştirmeye çaba gösterdi. Değişik tekniklerde yapılan son çalışmaları geleneksel kaligrafiden radikal bir şekilde ayrıldığını gösteriyor. Jabbari'nin araştırmaları geleneksel meşk anlayışını hatırlatıyordu ama, kelimelerive renkleri karıştırması onun soyutçu yönünü orataya koyuyordu. Buna rağmen diğer kaligraf sanatçları gibi bu ikisinin karışımı eserlerinde çok fazla olmuyordu. Kelimeler ve harfler artık standartlara sahip değiller ve içerikleriyle seyirciyle iletişime giremiyorlar, onun yerine renk ve dokuyla kendilerini gösteriyorlar (Görsel 21).

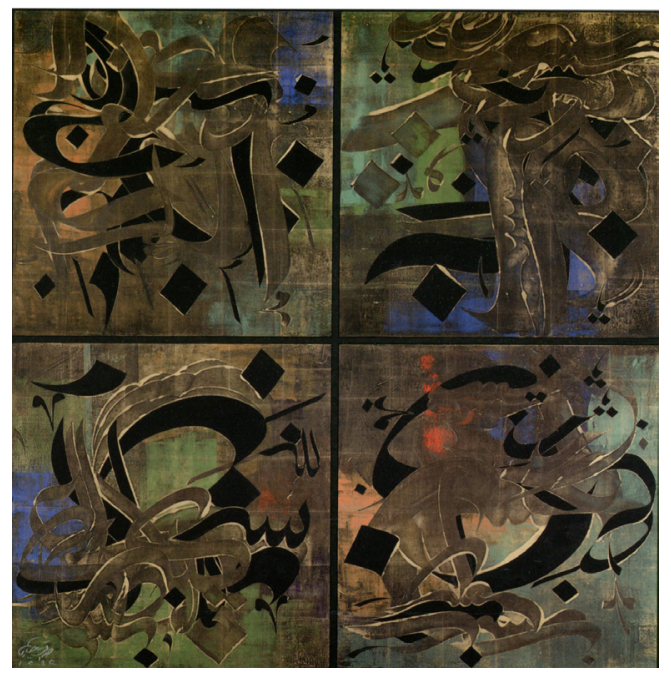

Görsel 21. Sedaghat Jabbari, Anonim, 2014,

Tuval üzerine yağılı boya, $180 \times 180 \mathrm{~cm}$, Sanatçııın Koleksiyonu.

\section{Grup: Soyut Geleneksel Kaligrafik Eğilimin Ressamları}

Mohammad Ehsaie (1939 d.), sanat kariyerine çocukluğundan beri aldığı geleneksel hat eğitimi ile başladı. Kaçar resim hat sanatına ve bilhassa da Mirza Gholam Rıza Esfahani'nin çalı̧̧malarına ilgi duyarak geleneksel hat sanatında çok iyi bir yere gelmiştir. Profesyonel bir ressam ve kaligraf olan Ehsayi, kendisinin halis yenilikçi kaligrafi tarzının, kaligrafiyi sadece bir form olarak kullanan Sağahane eğiliminden tamamen farklı olduğuna inanıyordu. Derin dini inançları olan bu sanatçı, geleneksel kaligrafi şekilleri yapısını tuvallerinde kullanırken, geleneksel kaligrafi ve grafik arası bir estetik elde etmiş̧tir. Ehsayi eserlerinde kaligrafiyi görsel bir yenilik yaratmak için kullanmışıı. Sanatçı, 1968 yılından günümüze kadar olan eserlerinde, kaligrafi formlarını ve monokrom renk çemberini kullanarak üç boyutlu eserler yaratmıştır. Sülüs ve muhakkak yazılar, resmi güçlü kılmak adına çok organize ve yaratıcı şekilde işlenmiştir. İran devriminden sonraki eserlerde, Iran Klasik siirinden, Kuran ayeleriniden ve hadisleriden esinlenerek eserler vermiştir. Önceki kaligraflar gibi onun için de yazıların içeriği çok önem taşıyor. Ama o kelimeler, ayet veya şiir kaligramları görünsün diye herhang bir çaba sarf etmiyor. Şiirsel formları, siyah ve beyaz manevi, halis ve sihirli bir dünyayı yansitiyordu. Bu eserler bir tür "kutsal sanat" olduğundan, gökyüzünden gelen "kelam"ın yansıması olduğuna inanıyordu.

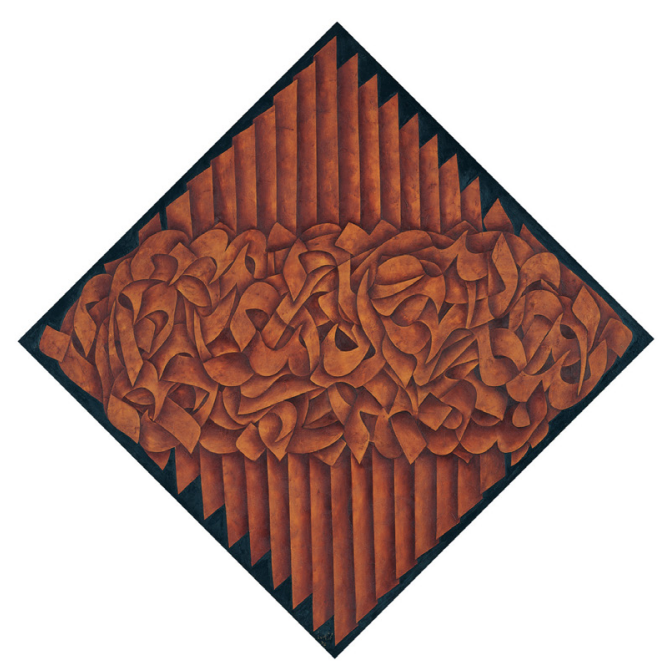

Görsel 22. Mohammah Ehsayi, Anonim, 1974

Tuval üzerine yağlıboya, $121 \times 120 \mathrm{~cm}$.

Bu grubun diğer önemli yüzü de Reza Mafi'dir, 1968 yılında İran Kaligrafi Derneği'nin eğitimini bitirmişti; ama ilk soyut geleneksel kaligrafik eserlerini, 1966 yllında bu dernekte eğitimine devam ettiği dönemde yaptı. O faaliyetlerine 1971 yılında siyah-meşk ile tek renk olarak başladı ama çok geçmeden tarzını değiştirdi. Her ne kadar ilk çalışmaları diğer nestalik ustalarının siyah-meşk eserlerine benzese de - grafik tekniklerin görselliğinde kullandığı harfler hem boyut, hem de ritmik kombinasyon açısından- diğerleri ile çok farklıydı. Bu özellik, daha sonraki eserlerinde daha da fazla görünüyor. $O$ ömrünün son yıllarında kahve ve sarı renkleri çok bol kullanmıştır. Mafi son yıllarında Sohrab Sepehri (1928-1980) şiirlerinde esinlenerek monokronm soyut geleneksel kaligrafik eserler de yarattı. 


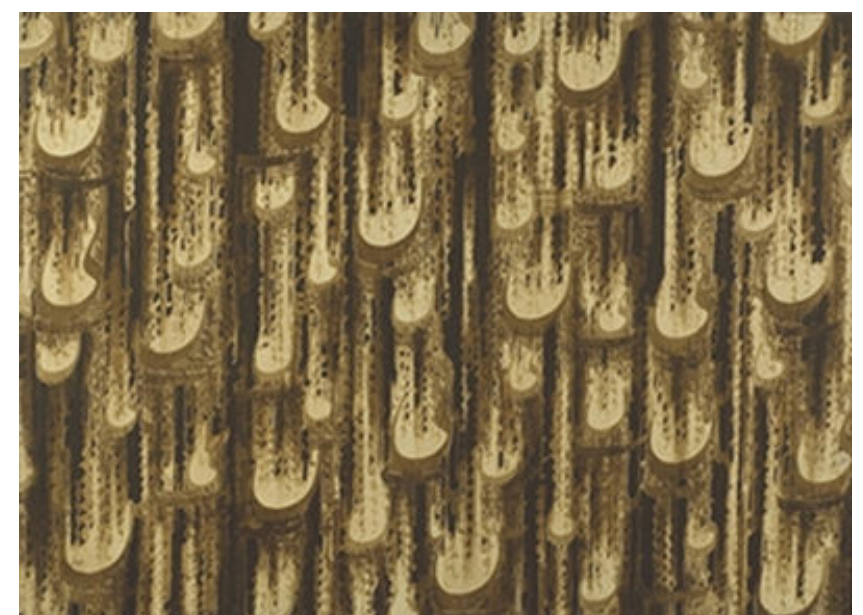

Görsel 23. Reza Mafi, Anonim,

Tuval Üzerine Yağlıboya, 1974,150x/10cm.

Nasr Allah Afjayi, geleneksel eğilimdeki soyut kaligrafinin diğer profesyonel bir sanatçısıdır. 1964 yılında Iran Kaligrafi Derneği'nin eğitimini tamamladı. Afjayi, kaligrafi uzmanı olarak hiçbir zaman soyut estetik kuralların tam olarak uymadı, çünkü bu şekilde kaligrafi kurallarını gözardı etmiş olacaktı. Soyut kaligrafinin geleneksel eserlerinde kufi, moalaghi, sülüs, nestalik ve şikeste yazı tiplerini kullandı. Bu eserlerin konusu daha çok edebi ve diniydi. 1972 yılından eserlerinde imza gibi elin hızlı hareketleri ile yapılan kaligrafilerle bassladı. Afjayi örneklerde kaligrafinin farkı tarzlarını Fars alfabesiyle ritmikşekilleryaratmakiçin kullandı. 1972 ve 1975 yılları arasında kufi ve sülüs yazı tiplerini kullandı. Onun, eski kaligrafi şekilleriyle yaptığı oyunlar, mimari ve İslam-iran kültürünü yansıtan yazıların birleşimini ve aynı zamanda kitaplardaki resimlerin içeriğini yazı ile hatıllatıyordu (R.24).

İran Kaligrafi Derneği, faaliyetlerini ülkenin dört bir yanına yayınca soyut kaligrafinin geleneksel eğilimini benimseyen sanatçılar (aynı zamanda önemli kaligraflar olan sanatçılar) da bu dönemde eserlerini sergilediler. Bu dönemdeki yeni kaligram sanatçılarının ilham kaynağını Sağahane yerine daha çok İslam-Iran eski kaligrafisi belirlemiştir. Afjayi ve Ali Vazirian gibi başarılı sanatçılar Sağahane tarzını geliştirmekte önemli roller üslendiler ve kendi eğilimlerini şekillendirip eserlerini sergileyebildiler. Ali Vazirian, soyut geometrik tarzda meydana getirdiği eserleriyle İslam kaligrafisi formuna ulaşmıştır. Mesela o, yatay ve dikey alanları belli bir perspektif içinde düzenleyerek, bazen koyu alanlara, bazen de açık alanlara $\mathrm{Hz}$. Ali adını yasmak suretiyle kendi tarzını yaratmıştır (Görsel 25).
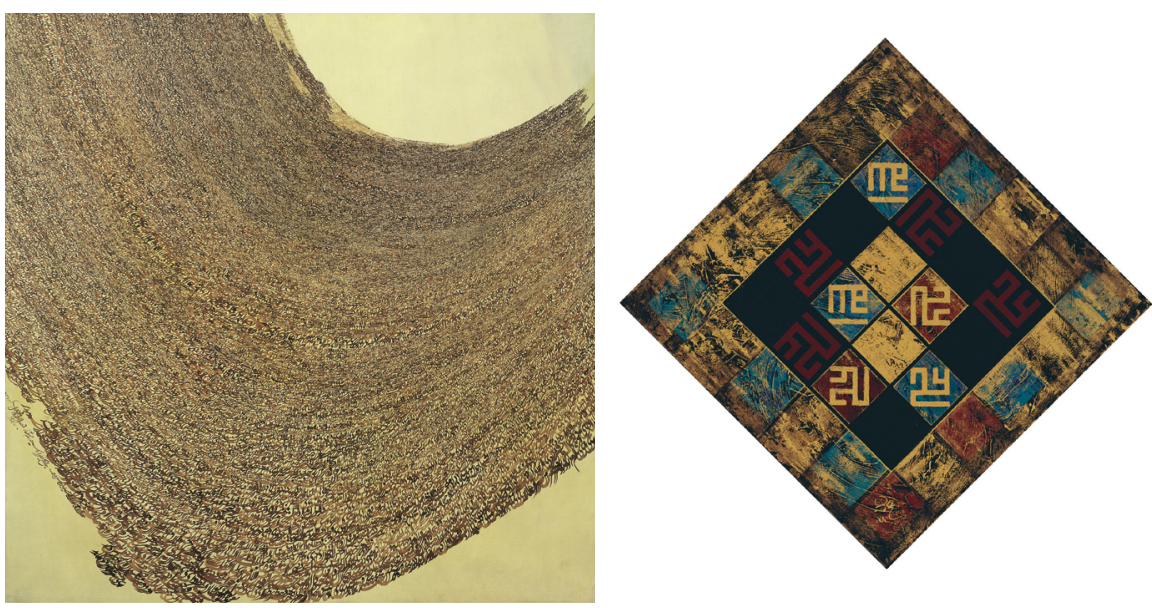

Görsel 24. Nasrollah Afjeie, Kaligrafi, Tuval üzerine yağlıboya, I 99 I, I35x/35cm.

Görsel 25. Ali Vazirian, Anonim, 1999, Tuval üzerine yağlıboya, $100 \times 100 \mathrm{~cm}$.

\section{Grup: Geleneksel Kaligrafik Eğilimin Ressamları}

Bu grubun sanatçısı, Jalil Rasouli (1947 d.) profesyonel faaliyetlerine 1970 'li yılların oratsında başlamasına rağmen 1980 ve 1990'lı yıllarda daha ünlü oldu. O da tuvalde resim tekniklerine çok meraklıydı. 1970'li yılların sonu ve 1980 'li yılların başında ilk geleneksel kaligrafik teknikler yaklaşımı eserlerinde, dini ve özellikle Kuran ve ahadis yazılarında faydalanarak figüratif şekillere şahit oluyoruz, sols yazı tipiyle yapılan bu eserler hayvan ve kuşları kullanarak anlamlı şekilleryapılan 19. Yüzyılın sanatını hatırlatıyor Rasoul Zaman'in çalışmaları gölge tekniğini kullandığında, Ehsayi'nin tuvallerine çok benziyor.

Ghorban Ali Ajali (1939 d.) yenilikçi kaligrafi de araştırmalar yapan diğer sanatçılardandır. Onun denemerli geleneksel kaligrafik eğilimin sanatçılarından çok fazla bilinen bir şey değildir. O, "golgasht" dediği kendine özgü tarzına daha düşkündü. $\mathrm{O}$, ilk golgasht koleksiyonunda, binlerce küçük ve büyük harfi kullanarak, doğada mevcut olan bir nesne veya portre yaratmıştır. 1990 ve 2000 'li yıllardaki kaligram eserlerinde artık bu yapı görünmüyor. Onun yerine, yuvalin tüm zeminini kapşayan tek renk halinde nestalik ve sülüsle yapılmış yazılardan meydana gelen kompozisyonlar görülüyor. 

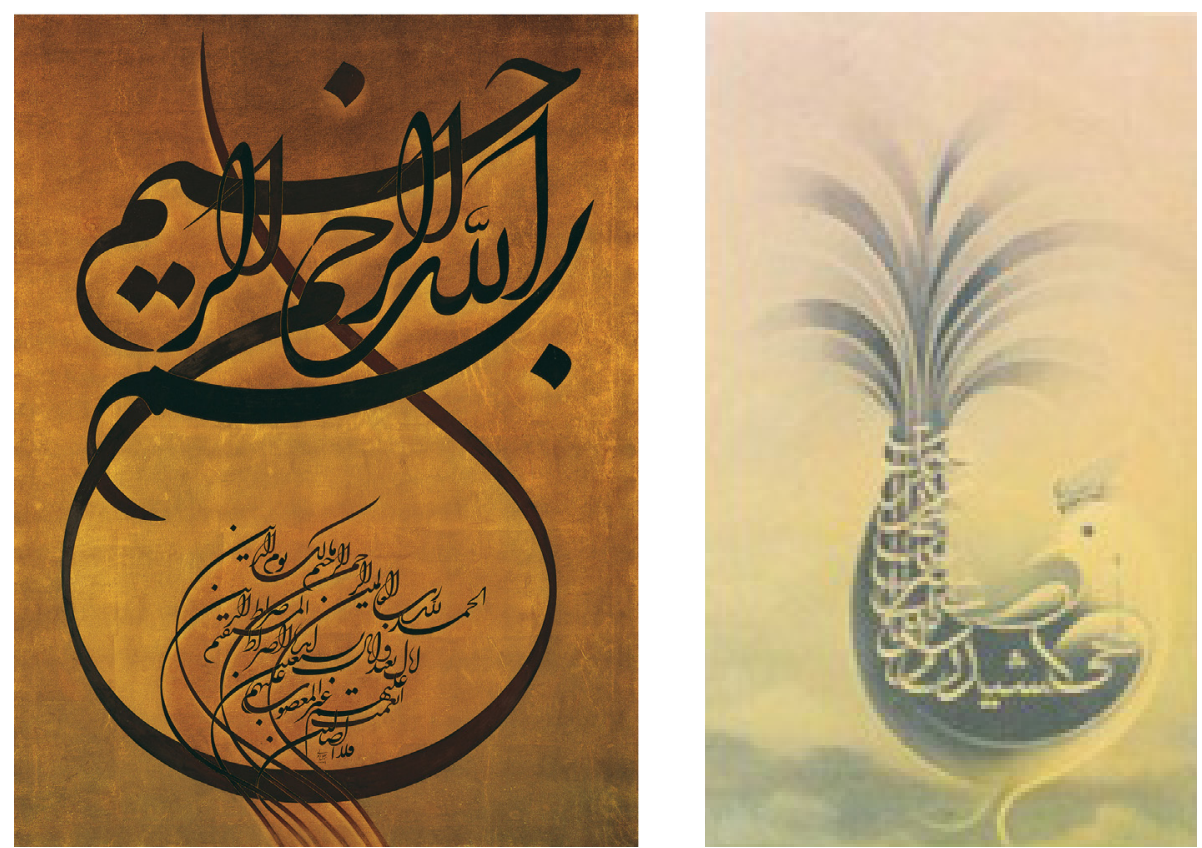

Görsel 26. Jalil Rasouli, Kaligram sülüs kaligrafisi ile, 1990, Tuval üzerine yağlıboya, 16 I $x 101 \mathrm{~cm}$

Görsel 27. Ghorban Ali Ajali, Golgasht, Kağıt üzerine mürrekep, $32 \times 23.5 \mathrm{~cm}$.

Ghorban Ali Ajali'nin çalışmaları, Rasouli'nin işleriyle aynı gruba girse bile içerik yönünden onun eserlerinden farklıdır. "Golgasht" denilen Ajali'nin çalışmaları, biçim ve içerikte herhangi bir özel oryantasyonu olmadan ve bir yorum yapmadan sadece doğayı temsil etmektedir. Oysa Ajali'nin eserlerinde ağaç, çalı ve dağ gibi doğa unsurları, kaligrafinin kullanması ile yaratılmışır.

Bu grubun kurallarını takip eden diğer kaligrafçılar ise şunlardır: Asad Allah Kiyani (1946), Taha Behbahani (1947), Ali Reza Karami (1949), Khosrow Roshan (1956), Ali Shirazi (1960), Eynoddin Sadeghzadeh (1965), Javad Bakhtiari (1956) Mehdi Fallah, Hamid Ajami (1962), Ahmad Mohammad Pour (1966) ve Ali Tan (1971).

\section{Sonuç}

Kültür; belli bir toplumun duyuş, biliş ve davranış kalıplarından oluşan maddi ve manevi de ğerlerin tümü olarak tanımlanır. Kültür; bir toplumda gelenekli halde yaşayan her türlü bilim, teknoloji, eğitim ve estetik alanlarındaki bütün faaliyetleri kapsar. Başka kültürlerden etkilenerek gelişir, değişir ya da başka kültürler içerisinde eriyerek kaybolur. Sanat, kültürün estetik alanını oluşturur. Sanatçı içinde yaşadığı toplumun sosyo-ekonomik, politik, kültürel ve dinsel koşullarından etkilenir ve onları etkiler. Sanatçının estetik duyarlığına, eserin içsel anlamına bağlı olarak değer kazanan sanat eserleri bu nedenle, çağının ve döneminin kültürel özelliklerini yansıtıllar. Böylece kültürün özelliklerini yansıtırken geleneksel çelişkileri de artar. Günümüzde sanat alanında yaşanan, gelenekli ve çağdaş sanat (modernsoyut) çekismesinin ana nedeni de budur. Geleneksel sanatın devam ettirilme çabalarını moderncilik ile bağdaştırmak, İran resim sanatında 50'li yılların sonundan itibaren hep olagelmiştir. Bazı yenilikçi İranlı ressamlar mevcut modernist atmosfere rağmen sanatın farklı dallarında geleneksel eğilimlerin peşinden giderek, İran kaligrafisine yöneldiler. Bu eğilimin Iran'ın geleneksel sanatlarından biri olduğunu göz önünde bulundurarak onun önemini anlayabiliriz.

Kaligrafi pek çok İslâm ülkesinde, i̇slâm öncesi kültürlerinin İslâmî devir kültürleriyle bütünleștirilmis olan maddi kültürel ürünleriden ve mimariden kullanım esyalarına kadar hemen hemen her alanda bir süs unsuru olarak karşımıza çımakta, bazen de kendi başına bir sanat eseri olma özelliğin sürdürmektedir. Kendi üslup farklılıklarını içerisinde barındıran bu gelenekli sanat ürünü, kendi ülke kültürlerinin dünyada tanınmasında ve bir değer olarak kabul edilmesinde çok büyük bir etkendir. Bunun yanı sıra, kaligrafi, kendi kültürel değerlerini özümseyerek, çağdaş sanat akımları doğrultusunda eserler vermek ve evrensel olana ulasmak da kültürlerin tanınmasında önemli bir unsurdur. Ayrıca dil, sesin olmadığı durumlarda yazı ile ifade edilir, yazının bir diğer anlamı ise kaligrafidir.

Böylece bazı İranlı sanatçılar, 50'li yıllardan sonra kaligrafiyi doğasından çıkarmaya çalışıp, formlar ve bilinir motiflerin araştırması sonucunda, İranlıİslam kaligrafisinin boyut ve șekil esnekliğinden temel görsel elemanlar ile birleştirerek eserlerinde kullanmaya başladılar. Sağahane mektebi bu eğilimin sanatçıları tarafında ortaya gelen eserlerinde önemli rolü oynamaktadır. Sağahane sanatçılarının asıl düşüncesi kadim İran sanatının özelliklerini tanımaktı. Bu yüzden İran sanatındaki kaligrafi eğilimlerin etkileşim sonraki kültürel ve sanatsal gelișmelerde de etkili oldu. Böylece İran resim sanatındaki kaligrafik eğilimlerin sanatçıları farklı formlar seçtiler: 
Sağahane sanatçıları (ressamları) ve onların takipçileri soyut eserleinde kaligrafiya yöneldiler, bu sanatçıların eserlerinde kaligrafi ana görsel eleman olarak, formların ve figürlerin yerini almıstır. Bu grubun karsıı karşıya gelen grup ise profesyonel kaligraflar, geleneksel içeriği ana elemanlar olarak eserlerinde kullandılar. Bu eğilim "soyut geleneksel kaligrafik ressamlar" ve "geleneksel kaligrafik ressamlar" olmak üzere kendi içinde iki gruba ayrılmıştır 


\section{Kaynakça}

Balaghi, Shiva. (2002). Iranian Visual Arts in The Century of Machinery, Speed and Atorn: Rethinking Modernity, in Shiva Balaghi, (Lynn Gumpert, ed), Picturing Iran: Art, Society and Revolution, London and New York.

Bayani, Mehdi. (1984). Biography and Calligraphers, Biography and Calligraphy works, Second Edition. Tehran: Elmi publication,

Caubet, Annie-pouyssegur. (1998). The Ancient Near East, Terrail, Paris.

Daneshvar, Simin. (1996). Recognition and Admiration of Art, Siamak book publication, Tehran.

Diba, Farah. (197I). Queen of the public, historians and artist's warnings, Tamasha Magazine, I97I (a), first year, No. VII, p. I2-I3 and 48-49.

Diba, Kamran. (1989). Iran, Contemporary Art from the Islamic World, (in Wijdan Ali, ed), London: Amman, p. 152

Ehsaei, Mohammad. (1986), “A journey in Calligraphy”, Honar Quarterly Magazine, Issue 10, p. I42-15I.

Ehsaei, Mohammad. (2009). Calligraphes knew me as a rascal, Etemad-e Melli News Paper, Number: 896, p. II -25.

Emami, Karim. (1977). look back to Saqakhaneh school, publication: Tehran Museum of Contemporary Art, 2536 Imperial Year, p. 17.

Keshmirshekan, Hamid. (2007). Contemporary Iranian Art: The Emergance of New Artistic Discourses, Iranian Studies, vol. XL, iii, pp.335-366.

Keshmirshekan Hamid. (2010). The Question of Identity vis-à-vis Exoticisim in Contemporary Iranian Art Iranian Studies, No.43, iv, pp.489-5 I 2.

Keshmirshekan, Hamid. (20II). Textual Elements in Modern and Contemporary Iranian Art, Art Tomorrow Magazine, Number 5, p. 166.

Milani, Mohsen. (2009). The İslamic Revolution, the reign of Pahlavi to the Islamic Republic, (translation: MojtabaAttarzadeh), Tehran: Gam-e No Publication.

Natel Khanleri, Parviz. (1945). Art and Society, Dar Sokhan Magazine, second year, No.5, pp.72-76.

Pakbaz, Ruin. (1999). Reflecting of traditions in Iran Modern Painting, Visual Arts

Magazine, Seventh year, Number two, 1999, s. 46-66.
Pakbaz, Ruin, Yaghoub Emdadian. (2002). Pioneer of Iranian Modern Art, M. Hosseini, Tehran: TMOCA Publication.

Shamkhani, Mohammad. (2003). Critics and Articles about Some of Pioneers of Contemporary Art of Iran, Tehran: Agah Publication, First Edition.

Tabrizi, Sadegh. A Dialouge with, Contemporary Painter: Sadegh Tabrizi, Talash Magazine, Number 5, 1985, p.98-1/5.

Tanavoli, Parviz. (2009). Atelier Kaboud, (in David Golloway, ed), Parviz Tanavoli: Sculptor, Writer and Collector, Tehran, 2009.

The fourth book of Shiraz Arts Festival, 1970, s. 12.

Welch, Anthony. (1979). Calligraphy in the Arts of the Muslim World, London: Kent.

Zenderoudi, Hossein. (200I). Hossein Zenderoudi's Abstract Calligraphy, Graphic Magazine, Number thirty-four, 200I, p. 23-35. 